\title{
Effect of transmembrane pressure control on energy efficiency during skim milk concentration by ultrafiltration at 10 and $50^{\circ} \mathrm{C}$
}

\author{
S. Méthot-Hains, ${ }^{*}$ S. Benoit, ${ }^{*}$ C. Bouchard, † A. Doyen, ${ }^{*}$ L. Bazinet, ${ }^{*}$ and Y. Pouliot ${ }^{* 1}$ \\ *STELA Dairy Research Center, Institute of Nutrition and Functional Foods, Department of Food Science, Université Laval, Québec, Canada, \\ G1V OA6 \\ †Department of Civil Engineering and Water Engineering, Université Laval, Québec, Canada, G1V 0A6
}

\section{ABSTRACT}

The efficiency of the ultrafiltration process during skim milk concentration was studied using both dynamic and constant (465 or $672 \mathrm{kPa}$ ) transmembrane pressure experiments at refrigerated temperature $\left(10^{\circ} \mathrm{C}\right)$ and high temperature $\left(50^{\circ} \mathrm{C}\right)$. The pilot-scale module was equipped with a $10-\mathrm{kDa}$ polyethersulfone spiral-wound membrane element with a surface area of $2.04 \mathrm{~m}^{2}$. Permeation flux, resistance-in-series model, mineral and protein rejection, and energy consumption were studied as a function of temperature and transmembrane pressure applied. Higher permeation flux values were systematically obtained at $50^{\circ} \mathrm{C}$. Also, a significant temperature effect was found for calcium rejection, which was lower at $10^{\circ} \mathrm{C}$ compared with $50^{\circ} \mathrm{C}$. Total hydraulic resistance and reversible fouling resistance were higher at $50^{\circ} \mathrm{C}$ than at $10^{\circ} \mathrm{C}$. No change in protein rejection was observed, depending on the operating mode studied. Permeation flux, which was higher at $50^{\circ} \mathrm{C}$, had lower pumping energy consumption compared with ultrafiltration at the colder temperature. Also, the low ultrafiltration temperature required a higher total energy consumption to reach the $3.6 \times$ retentate compared with ultrafiltration at $50^{\circ} \mathrm{C}$. Overall, our study shows that the operating parameters and temperature can be optimized using an energy efficiency ratio.

Key words: ultrafiltration, energy consumption, efficiency, transmembrane pressure

\section{INTRODUCTION}

Ultrafiltration is a process for concentrating skim milk proteins to produce protein concentrates (MPC) with a range of protein content from 42 to $85 \%$ (dry basis). Milk protein concentrates are widely used to

Received May 24, 2016.

Accepted August 3, 2016.

${ }^{1}$ Corresponding author: yves.pouliot@fsaa.ulaval.ca standardize cheese and milk protein content to improve profit by increasing yield, reducing fat losses in whey, and increasing the capacity of a cheese-making plant (Rehman et al., 2003; Guinee et al., 2006). Milk protein concentrate powders have several functional benefits such as emulsification and high reconstitution solubility, in addition to their nutritional value (functional ingredient) for a wide range of food products (Kelly, 2011; Sikand et al., 2011; Luo et al., 2015). Although producing MPC is relatively simple, it is essential to control and optimize technological parameters [temperature, transmembrane pressure (TMP), diafiltration, and so on] because they affect MPC composition, physical functionality, and operating costs. Producing high-quality products at minimal cost with low environmental impact is the major goal of the dairy industry's eco-efficiency concept. Eco-efficiency can be achieved by decreasing energy consumption while maintaining high permeation flux values. Operating temperature and TMP adjustments are 2 possible approaches for maximizing permeation flux, but their effect on energy consumption by the filtration units must be characterized.

Several studies have compared the $50^{\circ} \mathrm{C}$ and $10^{\circ} \mathrm{C}$ operating temperatures usually used to produce MPC from UF skim milk in terms of UF performance or retentate composition (Pompei et al., 1973; Kapsimalis and Zall, 1981; St-Gelais et al., 1992; Liu et al., 2014; Luo et al., 2015). Concentrating skim milk at low temperature is the best option for controlling microbial growth and minimizing protein denaturation (Pompei et al., 1973). During UF at $10^{\circ} \mathrm{C}$, permeation flux values decreased 4- to 5-fold compared with UF performed at $50^{\circ} \mathrm{C}$ (Pompei et al., 1973). Moreover, UF processing at low temperature increases water viscosity but also generates increased concentration polarization. Kapsimalis and Zall (1981) and St-Gelais et al. (1992) also studied the effects of temperature on permeation flux and microbial quality of UF skim milk retentates. Both studies showed that permeation flux values obtained with the same molecular weight cut-off (MWCO) 
membrane were improved at high temperature, but bacterial growth was also more important during UF at $50^{\circ} \mathrm{C}$. Conversely, Luo et al. (2015) found better permeation flux values, less membrane fouling, and shorter treatment time to final volume concentration factor at low temperature during UF of skim milk. Recent studies also focused on the effect of UF temperature on the composition and functionality of MPC. Luo et al. (2015) found better functionality (emulsification, solubility, and heat stability) when UF was performed at $15^{\circ} \mathrm{C}$, rather than at 30 or $50^{\circ} \mathrm{C}$. These authors also reported a decrease in casein micelle size at high temperature (from 92.7 to $83.6 \mathrm{~nm}$ ) at the end of the UF, disagreeing with the work of Liu et al. (2014), who observed a smaller change in the average micelle diameter during UF concentration. Luo et al. (2015) also demonstrated that a lower processing temperature removes more calcium. St-Gelais et al. (1992) showed that a low UF temperature reduced the buffering capacity of the skim milk concentrates, which increases the removal of soluble calcium and phosphorus.

The effect of TMP adjustments on UF membrane performance during skim milk concentration has been extensively studied. Grandison et al. (2000) characterized the effects of TMP on permeation flux and fouling during UF of skim milk at $50^{\circ} \mathrm{C}$. Similar to other studies, these authors showed that at constant wall shear stress, the fouling layer, which forms at higher TMP, governs the flux (Cheryan and Kuo, 1984; Razavi et al., 2003; Rinaldoni et al., 2009; Huang et al., 2014). Furthermore, according to Cheryan and Kuo (1984), the TMP and the temperature directly affect energy consumption by UF systems. More mechanical energy is required when the TMP is higher (Cheryan and Kuo, 1984). Using a 10-kDa UF cassette module, Rinaldoni et al. (2009) estimated the mechanical and thermal energy contributing to the UF system at different operating pressures (TMP of 50, 100, and $150 \mathrm{kPa}$ ) and temperatures $\left(20,30\right.$, and $\left.40^{\circ} \mathrm{C}\right)$, assuming ideal thermal insulation of the system. Their results suggested that maximum energy efficiency, in terms of thermal and mechanical energy contributed during processing, was achieved at room temperature and low pressure. Mechanical energy consumption increased with the TMP, but the thermal energy used to maintain the system's temperature was higher than the mechanical energy needed for feed pumping. They also showed that increasing the TMP increased the permeate volume. Increasing the temperature did not have the same effect.

To achieve the highest possible efficiency, losses in mechanical energy must be minimized. The energy losses of membrane systems are related to electric drives, pumps, membranes, valves, and system design. The study of technological alternatives to reduce the use of energy, including mechanical and thermal energy, can help dairy processors to improve the eco-efficiency of their operations.

Our aim was to characterize the performance (permeate flux decline, fouling resistance) and energy consumption (in situ measurement for mechanical and theoretically calculated for thermal energy) of a $10-\mathrm{kDa}$ polyethersulfone (PES) spiral-wound membrane during skim milk UF, as a function of TMP (2 constant TMP of 672 or $465 \mathrm{kPa}$, and one dynamic TMP ranging from 276 to $758 \mathrm{kPa}$ to maintain constant flux) and temperature $\left(10^{\circ} \mathrm{C}\right.$ and $\left.50^{\circ} \mathrm{C}\right)$.

\section{MATERIALS AND METHODS}

\section{Milk Supply and Preparation}

Whole raw milk (400 kg) purchased from a local cheese factory was warmed to $40^{\circ} \mathrm{C}$ with a heat exchanger and skimmed with a centrifugal cream separator (model MP1254, Westfalia, Oelde, Germany). The cream $(40 \mathrm{~kg}$ ) was discarded and the resulting raw skim milk $(360 \mathrm{~kg})$ was pasteurized with a HTST heat exchanger (APV, Goldsboro, NC) at $74^{\circ} \mathrm{C}$ for $16 \mathrm{~s}$, cooled to $4^{\circ} \mathrm{C}$, and stored at the same temperature until used.

\section{Ultrafiltration Process}

The pilot-scale UF system (GEA NIRO, Hudson, WI) included a stainless tank $(60 \mathrm{~L})$, a positive displacement feed pump (D/G-10, 576V , 5 HP Wanner International Ltd., Minneapolis, MN), 2 pressure gauges to monitor inlet and outlet pressure, and 1 membrane module. We used a PES spiral-wound UF module (Synder Filtration Inc., Vacaville, CA) with a MWCO of 10,000 Da. The module (model ST-3b-2540M) was $1.00 \mathrm{~m}$ long, with an internal diameter of $1.91 \mathrm{~cm}$, a feed spacer thickness of $1.17 \mathrm{~mm}$, and a membrane area of $2.04 \mathrm{~m}^{2}$. The same module and UF membrane were used for all UF experiments.

\section{Operating Conditions}

Before skim milk UF, pure water flux was measured using tap water $\left(10\right.$ or $\left.50^{\circ} \mathrm{C}\right)$ at a TMP of $620 \mathrm{kPa}$. Skim milk (60 kg batch size) was ultrafiltered at 2 different temperatures $\left(10\right.$ or $\left.50^{\circ} \mathrm{C}\right)$ and 3 different TMP, including 2 constant TMP of $672 \mathrm{kPa}$ (T1, maximum TMP recommended by the membrane supplier) and $465 \mathrm{kPa}$ (T2, minimum TMP to provide separation), and one dynamic TMP ranging from 276 to $758 \mathrm{kPa}$ (T3, TMP required to maintain a constant flux of 12.6 $\pm 4.00 \mathrm{~kg} / \mathrm{m}^{2} \cdot \mathrm{h}$ due to manual TMP adjustments by the operator). A tubular heat exchanger connected to 
an ice bath was placed into the UF tank to maintain a constant filtration temperature of $10^{\circ} \mathrm{C}$ during UF. Before UF was performed at high temperature, the skim milk was warmed to $50^{\circ} \mathrm{C}$, transferred to a stainless tank, and maintained at this temperature using a tubular heat exchanger. During UF concentration, the retentate was recycled back and the permeate was continuously removed from the system until a mean concentration factor $(\mathbf{C F})$ of $3.6 \times$, as determined by the weight $(\mathrm{kg})$ of permeate collected, was reached for all TMP and temperature conditions. Samples of permeate and retentate were collected at the beginning $(1 \times)$ and at the end $(3.6 \times)$ of UF and stored at $-20^{\circ} \mathrm{C}$ for subsequent analyses. The $\mathrm{pH}$ of all retentates was measured at the end of the process and was in the range of 6.5 to 6.7 .

\section{Cleaning Procedure}

Before and after each UF experiment, the membrane was rinsed and the water flux was measured using the same parameters as described for the initial clean water flux measurement. Immediately after rinsing, a first cleaning step was performed at $\mathrm{pH} 10.5$ with liquid alkaline membrane cleaner $(0.1 \mathrm{~mol} / \mathrm{L}$ of $\mathrm{NaOH}$; Ultrasil 25, Ecolab Inc., Laval, QC, Canada) followed by cleaning with citric acid solution at $0.1 \%$ (vol/vol; Ultrasil 76, Ecolab Inc.). The final cleaning stage was performed with Ultrasil 25 solution. Between all steps, the system was rinsed with tap water to reach a neutral $\mathrm{pH}$. At the end of the membrane cleaning procedure, the membrane water flux was always restored. Finally, the membrane was stored at $4^{\circ} \mathrm{C}$ in a $0.5 \%(\mathrm{vol} / \mathrm{vol})$ acid solution (Ultrasil MP, Ecolab Inc.).

\section{Determining Ultrafiltration Performance}

Permeation Flux. During UF experiment, permeation flux (J $\mathbf{J}$ Equation [1]) was measured every 10 min by weighing permeate collected in a flask during 1 min until a final volume concentration ratio (VCR) of $3.6 \times$. Permeation flux was expressed as a relative permeation flux $\left(\mathrm{J}_{\mathrm{r}}\right)$ by using Equation [2].

$$
\begin{gathered}
\mathrm{J}=\frac{\mathrm{F}_{\mathrm{p}}}{\mathrm{S}}, \\
\mathrm{J}_{\mathrm{r}}=\frac{\mathrm{J}}{\mathrm{TMP}},
\end{gathered}
$$

where $\mathrm{J}$ is the permeation flux $\left(\mathrm{kg} / \mathrm{h} \cdot \mathrm{m}^{2}\right), \mathrm{F}_{\mathrm{p}}$ is the permeation flow rate $(\mathrm{kg} / \mathrm{h}), \mathrm{S}$ is the surface area $\left(\mathrm{m}^{2}\right), \mathrm{J}_{\mathrm{r}}$ is the relative permeation flux $\left(\mathrm{kg} / \mathrm{m}^{2} \cdot \mathrm{h} \cdot \mathrm{Pa}\right)$, and TMP is the transmembrane pressure $(\mathrm{Pa})$.

Mean permeation flux $\mathrm{J}_{\mathrm{av}}\left(\mathrm{kg} / \mathrm{h} \cdot \mathrm{m}^{2}\right)$ was also calculated for each condition by determining the arithmetical mean value of all flux values between FCV 1 to $3.6 \times$.

Rejection Coefficient. The rejection coefficients $(\sigma)$ of the 10-kDa PES UF membrane for total nitrogen and calcium were determined using Equation [3].

$$
\sigma=1-\frac{\mathrm{C}_{\mathrm{p}}}{\mathrm{C}_{\mathrm{r}}}
$$

where $\mathrm{C}_{\mathrm{p}}$ and $\mathrm{C}_{\mathrm{r}}$ are the protein or calcium concentration in the permeate and retentate, respectively.

Membrane Resistance. Membrane fouling was characterized using the resistance-in-series model according to Equation [4] (Purkait et al., 2004).

$$
\mathrm{R}_{\mathrm{t}}=\mathrm{R}_{\mathrm{m}}+\mathrm{R}_{\mathrm{f}}=\mathrm{R}_{\mathrm{m}}+\mathrm{R}_{\mathrm{irr}}+\mathrm{R}_{\mathrm{rev}}
$$

where $R_{t}$ is the total resistance $\left(m^{-1}\right), R_{m}$ is the membrane resistance $\left(\mathrm{m}^{-1}\right)$, and $R_{\mathrm{f}}$ is the fouling resistance $\left(\mathrm{m}^{-1}\right)$, which is composed of the irreversible resistance $\left(\mathrm{m}^{-1}, \mathrm{R}_{\mathrm{irr}}\right)$ and the reversible resistance $\left(\mathrm{m}^{-1}, \mathrm{R}_{\text {rev }}\right)$. Membrane resistance $\left(R_{m}\right)$, as well as irreversible $\left(R_{\text {irr }}\right)$ and reversible $\left(\mathrm{R}_{\text {rev }}\right)$ fouling, can be determined using Equations [5], [6], and [7], respectively (Piry et al., 2012).

$$
\begin{gathered}
\mathrm{R}_{\mathrm{m}}=\frac{\mathrm{TMP}}{\mu \mathrm{J}_{\mathrm{w}}}, \\
\mathrm{R}_{\text {irr }}=\frac{\mathrm{TMP}}{\mu \mathrm{J}_{\mathrm{R}}}-\mathrm{R}_{\mathrm{m}}, \\
\mathrm{R}_{\text {rev }}=\frac{\mathrm{TMP}}{\mu \mathrm{J}_{\mathrm{E}}}-\mathrm{R}_{\mathrm{m}}-\mathrm{R}_{\text {irr }},
\end{gathered}
$$

where TMP is the transmembrane pressure $(\mathrm{Pa}), \mu$ is the permeate viscosity $\left(\mathrm{Pa} \cdot \mathrm{s}^{-1}\right), \mathrm{J}_{\mathrm{w}}$ is the water flux $\left(\mathrm{m}^{3} / \mathrm{m}^{2} \cdot \mathrm{s}\right), \mathrm{J}_{\mathrm{R}}$ is the water flux $\left(\mathrm{m}^{3} / \mathrm{m}^{2} \cdot \mathrm{s}\right)$ after membrane rinsing, and $J_{\mathrm{E}}$ is the permeation flux $\left(\mathrm{m}^{3} / \mathrm{m}^{2} \cdot \mathrm{s}\right)$ at the end of UF (at $3.6 \times$ ).

Energy Consumption. The total energy consumption $\left(\mathrm{E}_{\text {Total }}, \mathrm{kWh}\right)$ during UF experiments included the pumping energy $\left(E_{P}\right)$ and thermal energy $\left(E_{T}\right)$, and was calculated using Equation [8] (Cheryan, 1998):

$$
\mathrm{E}_{\text {Total }}=\mathrm{E}_{\mathrm{P}}+\mathrm{E}_{\mathrm{T}}
$$


Total pumping energy $\left(\mathrm{E}_{\mathrm{P}}, \mathrm{kWh}\right)$, calculated in realtime and every minute from the beginning of UF $\left(1.0 \times ; \mathrm{t}_{0}\right)$ until final CF $\left(3.6 \times ; \mathrm{t}_{\mathrm{f}}\right.$; Equation [9]), was obtained from data recorded by a voltmeter (model Fluke 3000FC, Montréal, QC, Canada) and 3 current clamps (model Fluke A3100FC) directly connected to the induction motor terminals of positive displacement pump:

$$
\mathrm{E}_{\mathrm{P}}=\int_{\mathrm{t}_{0}}^{\mathrm{t}_{\mathrm{f}}} \mathrm{P} \mathrm{dt}=\sum_{\mathrm{i}=1}^{\mathrm{n}} \mathrm{Pi} \Delta \mathrm{ti} .
$$

Power $(\mathrm{P}, \mathrm{kW})$ consumed by the pump at each minute during skim milk UF was obtained by Equation [10]:

$$
\mathrm{P}=\sqrt{3} \times \mathrm{U} \times \mathrm{I} \times \cos (\phi),
$$

where $\mathrm{U}$ is the voltage (volt), $\mathrm{I}$ is the current (A), and $\cos (\phi)$ (value from 0.37 to 0.55 ) is the power factor calculated as a function of pump load, according to the manufacturer's data.

The theoretical thermal energy $\left(\mathrm{E}_{\mathrm{T}} ; \mathrm{kWh}\right)$ used to obtain the required temperature $\left(10\right.$ or $\left.50^{\circ} \mathrm{C}\right)$ was estimated using Equation [11] (Rinaldoni et al., 2009):

$$
\mathrm{E}_{\mathrm{T}}=\mathrm{C}_{\mathrm{m}} \mathrm{m} \Delta \mathrm{T},
$$

where $\mathrm{C}_{\mathrm{m}}$ is the specific heat capacity of milk (0.92 $\left.\mathrm{kcal} / \mathrm{kg}^{\circ} \mathrm{C}\right), \mathrm{m}$ is the mass of skim milk $(\mathrm{kg})$, and $\Delta \mathrm{T}$ $\left({ }^{\circ} \mathrm{C}\right)$ is the difference between the initial temperature $\left(4^{\circ} \mathrm{C}\right)$ and the processing temperature of the milk (10 or $50^{\circ} \mathrm{C}$ ). For thermal energy calculations, we assumed the system had ideal thermal insulation and we did not account for the dissipation of mechanical energy.

The total energy consumption $\left(\mathrm{E}_{\text {Total }}\right)$ was expressed as the specific energy consumption (SEC), as proposed by $\mathrm{Xu}$ and Flapper (2011). In this study, the SEC is defined as final energy use $\left(\mathrm{E}_{\mathrm{P}}+\mathrm{E}_{\mathrm{T}}\right.$, Equation [7]; i.e., end-use energy) divided by the production quantity of a dairy product output ( $\mathrm{kg}$ of $3.6 \times$ concentrate; $\mathrm{Xu}$ and Flapper, 2011). Consequently, $\mathrm{E}_{\text {Total }}$ was expressed in kilowatt hours per kilogram of milk retentate.

\section{Analytical Methods}

Total solids of milk samples were measured using AOAC International (2000) method 925.23. The total $\mathrm{N}$ and NPN were determined using the Kjeldahl method according to ISO 8968-1 (ISO-IDF, 2001a) and ISO 8968-4 (ISO-IDF, 2001b), respectively. The calcium and phosphorus content was measured by inductively coupled plasma-optical emission photometer (Optima
4300, dual view, Perkin-Elmer, Norwalk, CT) with wavelengths of 327.396 and $178.287 \mathrm{~nm}$, respectively (Bazinet et al., 2000).

\section{Statistical Analysis}

All experiments were performed in duplicate. To determine the effect of operating parameters (pressure and temperature) on skim milk composition (TS, true protein, calcium, phosphorus), rejection coefficient, membrane resistance, and energy consumption, we performed a 2-way ANOVA in a complete block design, using the SAS GLIMMIX procedure (SAS version 9.3, SAS Institute Inc., Cary, NC). Protected Fisher's least significant difference tests were used to compare means $(\alpha=0.05)$ using the LSMEANS statement. To assess the effect of operating parameters on permeation flux as a function of $\mathrm{CF}$, a repeated 3-way ANOVA was performed using the SAS MIXED procedure. In case of significant interaction effects, we used the SLICE option of the LSMEANS statement to help interpret the interaction. The normality and homogeneity assumptions were verified.

\section{RESULTS}

\section{Effect of TMP and Temperature on Relative Permeation Flux}

Figure 1 shows the effect of constant (T1, T2) or dynamic TMP (T3) at operating temperatures of $10^{\circ} \mathrm{C}$ (Figure $1 \mathrm{~A}$ ) and $50^{\circ} \mathrm{C}$ (Figure $1 \mathrm{~B}$ ) on relative permeation flux as a function of CF during UF of skim milk (experimental data available in Supplemental Figure S1; http://dx.doi.org/10.3168/jds.2016-11504). Overall, relative permeation flux values were significantly higher $(P<0.05)$ at $50^{\circ} \mathrm{C}$ compared with $10^{\circ} \mathrm{C}$ whatever the operational conditions (T1 to T3). Permeation flux decreased continuously whatever the filtration temperature and TMP applied, but some differences were observed between treatments and temperatures.

At $10^{\circ} \mathrm{C}$, the relative permeation flux decline was similar $(P>0.05)$ for all TMP conditions. Indeed, relative permeation flux decreased from mean values of 2.5 $\times 10^{-5} \pm 0.8 \times 10^{-5} \mathrm{~kg} / \mathrm{m}^{2} \cdot \mathrm{h} \cdot$ Pa to $1.0 \times 10^{-5} \pm 0.02 \times$ $10^{-5} \mathrm{~kg} / \mathrm{m}^{2} \cdot \mathrm{h} \cdot \mathrm{Pa}$ at CF $3.6 \times$. No significant differences $(P>0.05)$ were observed between curves for T1, T2, and T3, indicating that pressure adjustment had no effect on relative permeation flux at $10^{\circ} \mathrm{C}$. Nevertheless, we noticed that a more constant relative flux was obtained with the low-pressure operation (T2), suggesting that this condition offers some advantages for longer filtration periods. 
When UF was performed at $50^{\circ} \mathrm{C}$, marked differences occurred in the changes in relative permeation flux according to the TMP operating mode. Relative permeation flux slightly decreased from $2.8 \times 10^{-5} \mathrm{~kg}$ / $\mathrm{m}^{2} \cdot \mathrm{h} \cdot \mathrm{Pa}$ to $1.5 \times 10^{-5} \mathrm{~kg} / \mathrm{m}^{2} \cdot \mathrm{h} \cdot \mathrm{Pa}$ at $\mathrm{CF} 3.6 \times$ for the high-pressure mode (T1), whereas higher flux values
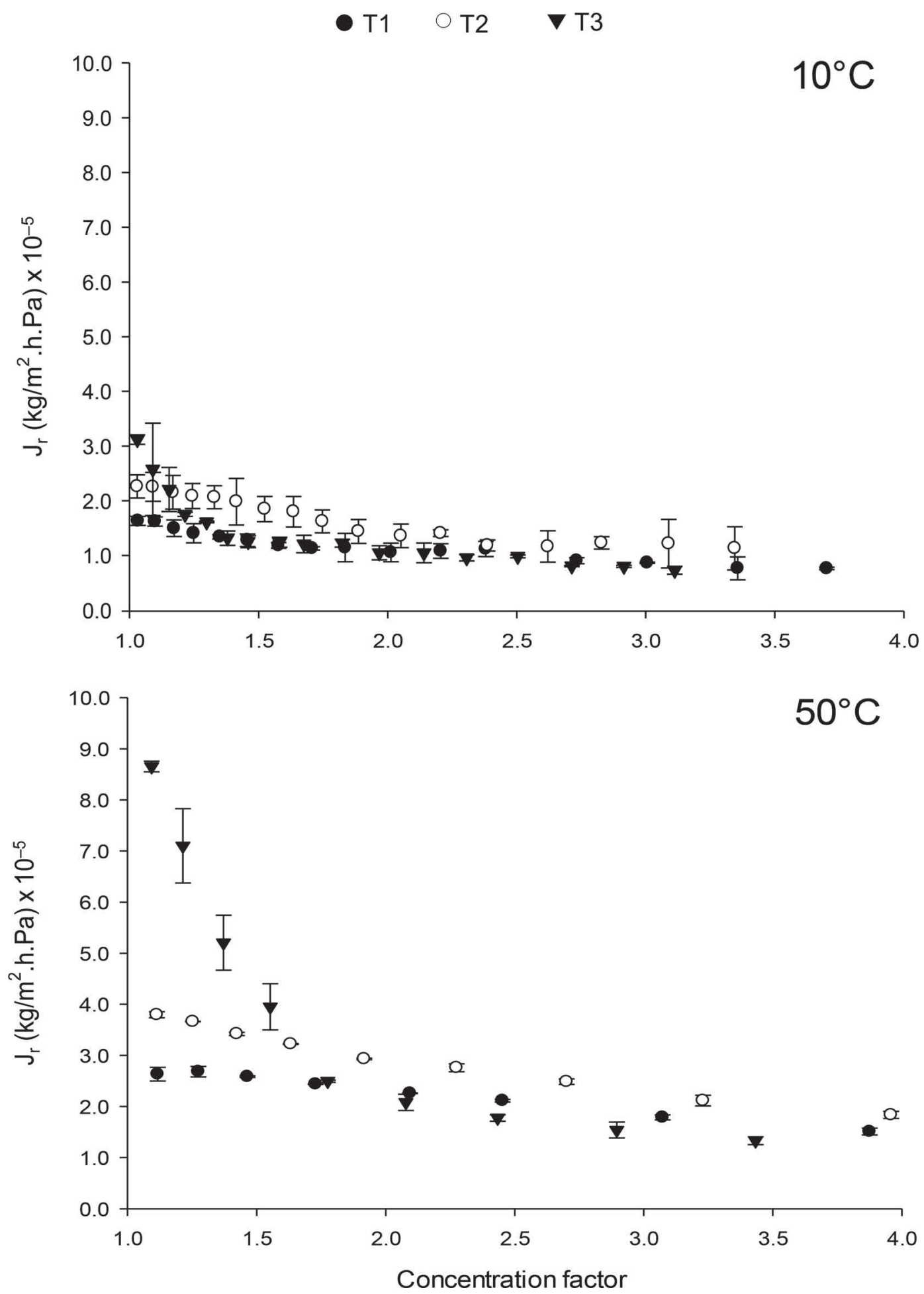

Figure 1. Effect of operating modes on relative permeation flux $\left(\mathrm{J}_{\mathrm{r}} ; \mathrm{kg} / \mathrm{m}^{2} \cdot \mathrm{h} \cdot \mathrm{Pa}\right)$ versus concentration factor $(\mathrm{CF})$ during UF of skim milk at constant transmembrane pressure (TMP; $672 \mathrm{kPa}, \mathrm{T} 1$, and $465 \mathrm{kPa}$, T2) and dynamic TMP (T3) at $10^{\circ} \mathrm{C}$ and at $50^{\circ} \mathrm{C}$. Error bars in indicate standard deviation of duplicate determinations. 
Table 1. Effect of operating mode on protein and mineral (calcium and phosphorus) content of UF skim milk retentate and permeate

\begin{tabular}{|c|c|c|c|c|c|c|c|}
\hline Item & Skim milk & \multicolumn{2}{|c|}{ UF retentates ${ }^{1}$} & $P$-value ${ }^{2}$ & \multicolumn{2}{|c|}{ UF permeates } & $P$-value \\
\hline $\begin{array}{l}\mathrm{TS}^{3}(\%) \\
\text { True protein }(\%) \\
\text { Calcium }(\mathrm{m} M) \\
\text { Phosphorus }(\mathrm{m} M) \\
\sigma_{\mathrm{Ca}}{ }_{4}\end{array}$ & $\begin{array}{l}9.29 \pm 0.02 \\
34.7 \pm 2.85 \\
31.6 \pm 1.56 \\
34.2 \pm 0.85\end{array}$ & $\begin{aligned} 16.92 & \pm 0.36 \\
55.01 & \pm 0.99 \\
70.09 & \pm 2.08 \\
62.34 & \pm 1.75 \\
0.67 & \pm 0.01\end{aligned}$ & $\begin{aligned} 18.10 & \pm 0.21 \\
60.74 & \pm 0.78 \\
80.22 & \pm 1.24 \\
69.44 & \pm 1.07 \\
0.77 & \pm 0.00\end{aligned}$ & $\begin{array}{l}<0.01 \\
<0.01 \\
<0.01 \\
<0.01 \\
<0.01\end{array}$ & $\begin{array}{l}5.78 \pm 0.25 \\
41.2 \pm 1.43 \\
20.8 \pm 0.90 \\
30.3 \pm 1.00\end{array}$ & $\begin{array}{r}5.93 \pm 0.26 \\
40.30 \pm 0.60 \\
13.20 \pm 1.20 \\
24.50 \pm 2.64\end{array}$ & $\begin{array}{l}\mathrm{NS} \\
\mathrm{NS} \\
<0.01 \\
<0.01\end{array}$ \\
\hline
\end{tabular}

${ }^{1}$ Mean concentration factor $(\mathrm{CF})$ at $10^{\circ} \mathrm{C}=3.5$; mean $\mathrm{CF}$ at $50^{\circ} \mathrm{C}=3.69$.

${ }^{2} P$-value compared retentate and permeate compositions at 10 and $50^{\circ} \mathrm{C}$.

${ }^{3}$ Expressed on dry basis, conversion factor: $\mathrm{N} \times 6.38$.

${ }^{4}$ Rejection coefficient $(\sigma)$ of calcium.

$\left(3.9 \times 10^{-5} \mathrm{~kg} / \mathrm{m}^{2} \cdot \mathrm{h} \cdot \mathrm{Pa}\right.$ to $\left.2.5 \times 10^{-5} \mathrm{~kg} / \mathrm{m}^{2} \cdot \mathrm{h} \cdot \mathrm{Pa}\right)$ were obtained for the low-pressure mode (T2). A different trend was observed for constant flux operating mode (T3) where flux sharply decreased from $8.8 \times 10^{-5} \mathrm{~kg} /$ $\mathrm{m}^{2} \cdot \mathrm{h} \cdot \mathrm{Pa}$ to $1.8 \times 10^{-5} \mathrm{~kg} / \mathrm{m}^{2} \cdot \mathrm{h} \cdot \mathrm{Pa}$ as the $\mathrm{CF}$ increased to $2.4 \times$, with a specific decrease in flux of $58 \%$ from 1.0 to $1.75 \times$. From 2.4 to $3.6 \times \mathrm{CF}$, the relative permeation flux remained constant. Because of the sharp decrease in relative permeation flux under T3 and the lower flux values under $\mathrm{T} 1$, we estimate that $\mathrm{T} 2$ operating mode offers advantages in performance because relative permeation flux remained constant from 1.0 to $3.6 \times$, was higher than T1 during all UF steps and T3 from $1.5 \times$ until the end of filtration.

\section{Effect of TMP and Temperature on Retentate Composition and Milk Component Rejection}

Table 1 reports the final retentate composition in terms of TS, true proteins, calcium, and phosphorus content. Because TMP operating modes (T1, T2, and T3) had no significant effect on the composition of UF retentates at each temperature, the data were pooled in 2 groups $\left(10\right.$ and $\left.50^{\circ} \mathrm{C}\right)$. Significant temperature effects $(P<0.01)$ were observed for all components analyzed in retentates. The TS, true proteins, calcium, and phosphorus values were all higher in retentates prepared at $50^{\circ} \mathrm{C}$. The rejection coefficient $(\sigma)$ for calcium, but not nitrogen, was significantly higher $(P<0.01)$ at $50^{\circ} \mathrm{C}$ compared with $10^{\circ} \mathrm{C}$, whatever the TMP operating mode (T1, T2, or T3).

\section{Effect of TMP and Temperature on Membrane and Fouling Resistances}

Table 2 reports the membrane resistance $\left(R_{m}\right)$ as well as reversible $\left(R_{r}\right)$ and irreversible fouling resistances $\left(\mathrm{R}_{\text {irr }}\right)$ for each TMP operating mode (T1, T2, and T3) at 10 and $50^{\circ} \mathrm{C}$. Membrane resistance $\left(\mathrm{R}_{\mathrm{m}}\right)$ and irreversible resistance $\left(\mathrm{R}_{\text {irr }}\right)$ were strongly influenced $(P<0.0001)$ by temperature, whereas TMP operating mode had no significant effect. Membrane resistance was higher at $50^{\circ} \mathrm{C}$ than at $10^{\circ} \mathrm{C}\left(11.12 \pm 0.08 \times 10^{12}\right.$ $\mathrm{m}^{-1}$ vs. $\left.6.57 \pm 0.29 \times 10^{12} \mathrm{~m}^{-1}\right)$ but $\mathrm{R}_{\text {irr }}$ was lower $\left(0.88 \pm 0.01 \times 10^{12} \mathrm{~m}^{-1}\right.$ vs. $\left.1.24 \pm 0.03 \times 10^{12} \mathrm{~m}^{-1}\right)$. Reversible resistance $\left(\mathrm{R}_{\text {rev }}\right)$ increased significantly $(P$ $<0.01)$ at $50^{\circ} \mathrm{C}$ compared with $10^{\circ} \mathrm{C}(3.31 \pm 0.25 \times$ $10^{12} \mathrm{~m}^{-1}$ vs. $\left.2.02 \pm 0.29 \times 10^{12} \mathrm{~m}^{-1}\right)$. Interestingly, the low-pressure operating mode (T2) induced lower $\mathrm{R}_{\mathrm{rev}}$ values $(P<0.05)$ compared with the 2 other modes at both temperatures.

Overall, total resistance values $\left(\mathrm{R}_{\mathrm{t}}\right)$ were higher at $50^{\circ} \mathrm{C}(P<0.01)$ and the T2 mode induced lower $\left(\mathrm{R}_{\mathrm{t}}\right)$ values $(P<0.01)$ compared with the 2 other modes at

Table 2. Effect of operating mode on membrane resistance $\left(R_{m}\right)$, irreversible resistance $\left(R_{\text {irr }}\right)$, reversible resistance $\left(R_{\text {rev }}\right)$, and total resistance $\left(\mathrm{R}_{\mathrm{t}}\right.$; mean $\left.\pm \mathrm{SE}\right)$ for producing a $3.6 \times$ skim milk retentates by $\mathrm{UF}$

\begin{tabular}{|c|c|c|c|c|c|c|c|}
\hline $\begin{array}{l}\text { Resistance } \\
\left(\mathrm{m}^{-1}\right)\end{array}$ & \multicolumn{3}{|c|}{ Temperature } & \multicolumn{4}{|c|}{ Operating mode } \\
\hline $\mathrm{R}_{\mathrm{m}}\left(\times 10^{12}\right)$ & $6.57 \pm 0.29$ & $11.12 \pm 0.08$ & $* * *$ & $8.65 \pm 1.34$ & $9.01 \pm 1.25$ & $8.89 \pm 1.42$ & NS \\
\hline $\mathrm{R}_{\mathrm{rev}}\left(\times 10^{14}\right)$ & $2.02 \pm 0.29$ & $3.31 \pm 0.25$ & $* *$ & $2.81 \pm 0.35^{\mathrm{a}}$ & $1.96 \pm 0.45^{\mathrm{b}}$ & $3.23 \pm 0.43^{\mathrm{a}}$ & $*$ \\
\hline $\mathrm{R}_{\mathrm{t}}\left(\times 10^{14}\right)$ & $3.33 \pm 0.30$ & $4.30 \pm 0.26$ & $* *$ & $3.98 \pm 0.23^{\mathrm{a}}$ & $3.09 \pm 0.39^{\mathrm{b}}$ & $4.37 \pm 0.36^{\mathrm{a}}$ & $* *$ \\
\hline
\end{tabular}

${ }^{\mathrm{a}, \mathrm{b}}$ Different superscripts indicate significant differences between applied pressures.

${ }^{1} \mathrm{~T} 1=672 \mathrm{kPa} ; \mathrm{T} 2=465 \mathrm{kPa} ; \mathrm{T} 3=$ dynamic flux.

${ }^{*} P<0.05$; ${ }^{* *} P<0.01$; *** $P<0.0001$. 
any temperature. The constant flux mode (T3) induced the highest $R_{\text {rev }}$ values for all conditions.

\section{Effect of TMP and Temperature on Energy Consumption}

Figure 2 illustrates the requirements in mechanical $\left(\mathrm{E}_{\mathrm{P}}\right)$ and thermal $\left(\mathrm{E}_{\mathrm{T}}\right)$ energy $(\mathrm{kWh} / \mathrm{kg}$ of retentate $)$ for the production of $\mathrm{CF} 3.6 \times$ retentate under each TMP operating mode at 10 and $50^{\circ} \mathrm{C}$. The TMP operating mode had no significant effect on $\mathrm{E}_{\mathrm{T}}$ or $\mathrm{E}_{\mathrm{P}}$ values at both temperatures. However, UF temperature resulted in highly significant differences $(P<0.0001)$ for both $\mathrm{E}_{\mathrm{T}}$ and $\mathrm{E}_{\mathrm{P}}$. Indeed, $\mathrm{E}_{\mathrm{P}}$ was 2.3 times higher at $10^{\circ} \mathrm{C}$ compared with $50^{\circ} \mathrm{C}$ with values of $0.28 \pm 0.02$ and $0.12 \pm 0.00 \mathrm{kWh} / \mathrm{kg}$, respectively. Conversely, the thermal energy needed to maintain milk at $50^{\circ} \mathrm{C}$ was 4.5 times higher compared with $10^{\circ} \mathrm{C}$, with values of $0.16 \pm 0.01$ and $0.035 \pm 0.001 \mathrm{kWh} / \mathrm{kg}$, respectively. When changed, only temperature significantly affected $(P<0.01)$ the total energy requirement $\left(\mathrm{E}_{\mathrm{T}}+\mathrm{E}_{\mathrm{P}}\right)$, and this was higher at $10^{\circ} \mathrm{C}(0.32 \pm 0.02 \mathrm{kWh} / \mathrm{kg})$ than at $50^{\circ} \mathrm{C}(0.28 \pm 0.01 \mathrm{kWh} / \mathrm{kg})$.

\section{DISCUSSION}

Our results provide evidence that temperature adjustments $\left(10\right.$ vs. $\left.50^{\circ} \mathrm{C}\right)$ had more significant effects on flux and hydraulic resistance compared with the effects of TMP operating regimens (T1, T2, and T3). The effect of TMP operating regimens has been limited to some flux decline characteristics at the beginning of UF experiments (e.g., under $\mathrm{T} 3$ at $50^{\circ} \mathrm{C}$ ).

We systematically obtained higher relative permeation flux values at $50^{\circ} \mathrm{C}$. Other studies also reported a significant reduction in permeation flux at low temperature (Pompei et al., 1973; Kapsimalis and Zall, 1981; St-Gelais et al., 1992; Luo et al., 2015).

This effect can result from increased water viscosity as the UF temperature decreases to $10^{\circ} \mathrm{C}$. As temperature affects filtration fluid viscosity, according to Equation [1], flux $(\mathrm{J})$ is inversely related to permeate viscosity $(\mu)$. Our results also show that at low temperature $\left(10^{\circ} \mathrm{C}\right)$, some calcium and phosphate were solubilized in the serum phase because decreases in those mineral contents were observed in the retentate at $10^{\circ} \mathrm{C}$ compared with $50^{\circ} \mathrm{C}$ at $\mathrm{CF} 3.6 \times$.

Temperature-dependent changes in permeation flux during UF concentration of milk may also be related to changes in soluble-colloidal equilibrium, which, in turn, may affect protein deposition on the UF membrane. Soluble-colloidal equilibrium between casein micelles and milk serum is profoundly affected by temperature (Horne, 2006). Luo et al. (2015) found that casein mi-

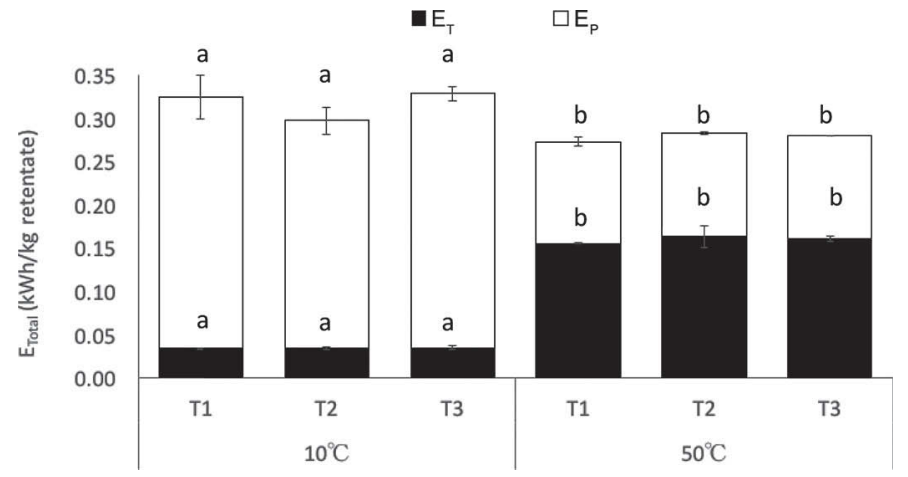

Figure 2. Total energy $\left(\mathrm{E}_{\text {Total }}, \mathrm{kWh} / \mathrm{kg}\right.$ of retentate) used as a function of operating conditions (dynamic and constant transmembrane pressure, $10^{\circ} \mathrm{C}$ and $50^{\circ} \mathrm{C}$ ) for the production of $1 \mathrm{~kg}$ at volume concentration ratio of $3.6 \times$, including the thermal $\left(\mathrm{E}_{\mathrm{T}}\right)$ and pumping energy $\left(\mathrm{E}_{\mathrm{P}} ; \mathrm{T} 1=672 \mathrm{kPa} ; \mathrm{T} 2=465 \mathrm{kPa} ; \mathrm{T} 3=\right.$ dynamic flux $)$. Different letters indicate significant differences for $\mathrm{E}_{\mathrm{T}}$ and $\mathrm{E}_{\mathrm{p}}$ as a function of operational conditions. Error bars in indicate standard deviation of duplicate determinations.

celles obtained from UF retentates prepared at $15^{\circ} \mathrm{C}$ had lower zeta potential compared with those obtained by $\mathrm{UF}$ at $50^{\circ} \mathrm{C}$.

We also observed that permeation flux decline profiles were similar for all TMP operating modes (T1, T2, T3) at $10^{\circ} \mathrm{C}$ but not at $50^{\circ} \mathrm{C}$. These results agree with recent observations by Luo et al. (2015) who found that the rate of flux decline was more rapid during the initial operation for the UF at $50^{\circ} \mathrm{C}$ compared with $\mathrm{UF}$ at $15^{\circ} \mathrm{C}$. These authors related this observation to increased deposition of calcium and protein on the membrane surface at $50^{\circ} \mathrm{C}$. The distinctive flux decline observed during the $\mathrm{T} 3$ operating mode at $50^{\circ} \mathrm{C}$ between $\mathrm{CF} 1.0$ to $2.4 \times$ can be explained by the rapid concentration polarization of solutes at the membrane surface, resulting from the convective flow at high flux values. At $\mathrm{CF}>2.4 \times$, the concentration polarization layer is more compact and its permeability gradually decreases.

The retentate compositions agree with published reports that lower temperatures decrease the proportion of colloidal calcium and phosphorus after UF of skim milk with membranes with MWCO ranging from 10 to $50 \mathrm{kDa}$ (Brule et al., 1974; Kapsimalis and Zall, 1981; Luo et al., 2015). Also, studies by Miller et al. (2014) revealed that over the threshold flux, at constant TMP and constant flux, rejection of organic particles increases as the TMP increases because the dynamic cake layer formed acts as another barrier to the particles (Miller et al., 2014). In contrast, we did not observe significant differences between calcium and nitrogen rejection at either constant or dynamic TMP. This can be explained by the fact that Miller et al. (2014) used UF membranes with MWCO of $20 \mathrm{kDa}$ or because we 
observed similar fouling at constant and dynamic flux because all the true proteins were retained with the 10-kDa MWCO membranes.

We found that temperature had a strong and significant effect $(P<0.0001)$ on membrane resistance $\left(\mathrm{R}_{\mathrm{m}}\right)$, which was higher at $50^{\circ} \mathrm{C}$. Stade et al. (2015) showed that PES and regenerated cellulose with MWCO of 20 and $30 \mathrm{kDa}$, respectively, were subjected to compaction at $50^{\circ} \mathrm{C}$ and $\mathrm{R}_{\mathrm{m}}$ increased with temperature due to changes in the viscoelastic properties of the polymeric layer (Stade et al., 2015). These findings suggest that membrane compaction increases the total hydrodynamic resistance, which negatively affects permeability. Increasing the temperature to $50^{\circ} \mathrm{C}$ decreased $\mathrm{R}_{\text {irr }}(P<$ $0.0001)$ but increased $\mathrm{R}_{\text {rev }}(P<0.001)$. Also, at both UF temperatures, the contribution of $R_{\text {rev }}$ was more important than that of $\mathrm{R}_{\text {irr. }}$. These observations agree with those of Grandison et al. (2000), who demonstrated that the contribution of irreversible fouling to total hydraulic resistance was low compared with reversible fouling when skim milk was ultrafiltered at $50^{\circ} \mathrm{C}$ with a $200-\mathrm{kDa}$ tubular membrane (Grandison et al., 2000). The same conclusion was reached by Muthukumaran et al. (2007) and Macedo et al. (2015), who used different $10-\mathrm{kDa}$ UF membrane materials to concentrate cheese whey. Our data contrasted, however, with the conclusions of Luo et al. (2015), who showed that more fouling occurred at high temperature during UF of skim milk. We must emphasize that none of these published data were obtained using spiral-wound elements, especially for Luo et al. (2015), who used flat-sheet membrane coupons. Such a laboratory-scale membrane system generates different hydrodynamic conditions and directly affects results on propensity for membrane fouling.

The hydraulic resistance values obtained under the TMP operating regimens were not statistically different, except for $\mathrm{R}_{\text {rev }}$ which was lower $(P<0.05)$ for $\mathrm{T} 2$, compared with T1 and T3. Some studies have demonstrated that at high TMP, a more compact and compressed deposit layer structure occurs, which is responsible for the increase in reversible fouling (Gésan et al., 1994; Samuelsson et al., 1997; Carić et al., 2000). Also, Miller et al. (2014) reported that constant permeation flux operation caused the continuous accumulation of fouling on the membrane (i.e., increasing total hydraulic resistance), compared with constant TMP where the fouling deposit remained constant. We were unable to confirm these hypotheses in this study.

Our energy consumption data provides strong evidence for the effect of UF temperature. First, the thermal energy consumption required to produce $1 \mathrm{~kg}$ of $3.6 \times$ retentate was lower at $10^{\circ} \mathrm{C}$ than at $50^{\circ} \mathrm{C}$, agreeing with Rinaldoni et al. (2009). However, we must mention that the energy required to maintain skim milk at 10 or $50^{\circ} \mathrm{C}$, the dissipation of mechanical work into heat by the feed pump and the energy loss during UF were not included in the calculation. Consequently, we likely underestimated the thermal energy consumption. Second, producing a $3.6 \times$ milk retentate at $10^{\circ} \mathrm{C}$ required 2.3 times more pumping energy $(0.28 \pm 0.02 \mathrm{kWh} / \mathrm{kg})$ than operating at $50^{\circ} \mathrm{C}(0.12 \pm 0.002 \mathrm{kWh} / \mathrm{kg})$, whatever the TMP operating mode. This difference could be explained by the higher fluid viscosity value at lower temperatures compared with $50^{\circ} \mathrm{C}$. Third, the mechanical energy data obtained for UF of skim milk at $50^{\circ} \mathrm{C}$ agree with the results of $\mathrm{Xu}$ and Flapper (2011), who reported a reference SEC value, based on global dairy plants, of $0.11 \mathrm{kWh}$ of electricity and $0.36 \mathrm{kWh}$ of fuel to produce $1 \mathrm{~kg}$ of concentrated milk (Xu and Flapper, 2011).

Using the total energy consumption as an indicator helps assess the effect of different TMP regimens and temperatures on the efficiency of the UF concentration process. Figure 3 illustrates the relationship between mean permeation flux $\left(\mathrm{kg} / \mathrm{m}^{2} \cdot \mathrm{h}\right)$ and total energy consumption $(\mathrm{kWh} / \mathrm{kg}$ of retentate) for the different TMP (T1, T2, T3) and temperatures $\left(10\right.$ and $\left.50^{\circ} \mathrm{C}\right)$. The graph has been divided into 4 quadrants to make data interpretation easier. The most efficient conditions in terms of flux and energy consumption is when flux is maximal and energy consumption is minimal. Figure 3 shows that optimal energy efficiency is achieved when the UF is operated at high temperature compared with low temperature. We also observed improved energy efficiency when the TMP was low (i.e., T2 operating mode; $465 \mathrm{kPa}$ at 50 and $10^{\circ} \mathrm{C}$ ), compared with the high and dynamic TMP. However, the high (T1) TMP operating mode has an energy efficiency ratio between the dynamic (T3) and the low (T2) TMP at 10 and $50^{\circ} \mathrm{C}$. Overall, the optimal energy efficient operating mode will be at a low constant TMP at $50^{\circ} \mathrm{C}$.

\section{CONCLUSIONS}

Permeation flux values were increased at $50^{\circ} \mathrm{C}$ compared with $10^{\circ} \mathrm{C}$, whatever the TMP. To save energy, processors should consider ultrafiltering skim milk at $50^{\circ} \mathrm{C}$, which requires 2.3 times less pumping energy compared with ultrafiltering at $10^{\circ} \mathrm{C}$, even if more thermal energy must be applied. When scaling up the process to higher working volumes, processors should calculate the energy efficiency ratio because operating the UF at low constant TMP is more efficient. This study will help dairy processors to determine the optimal parameters needed to improve UF energy efficiency. 


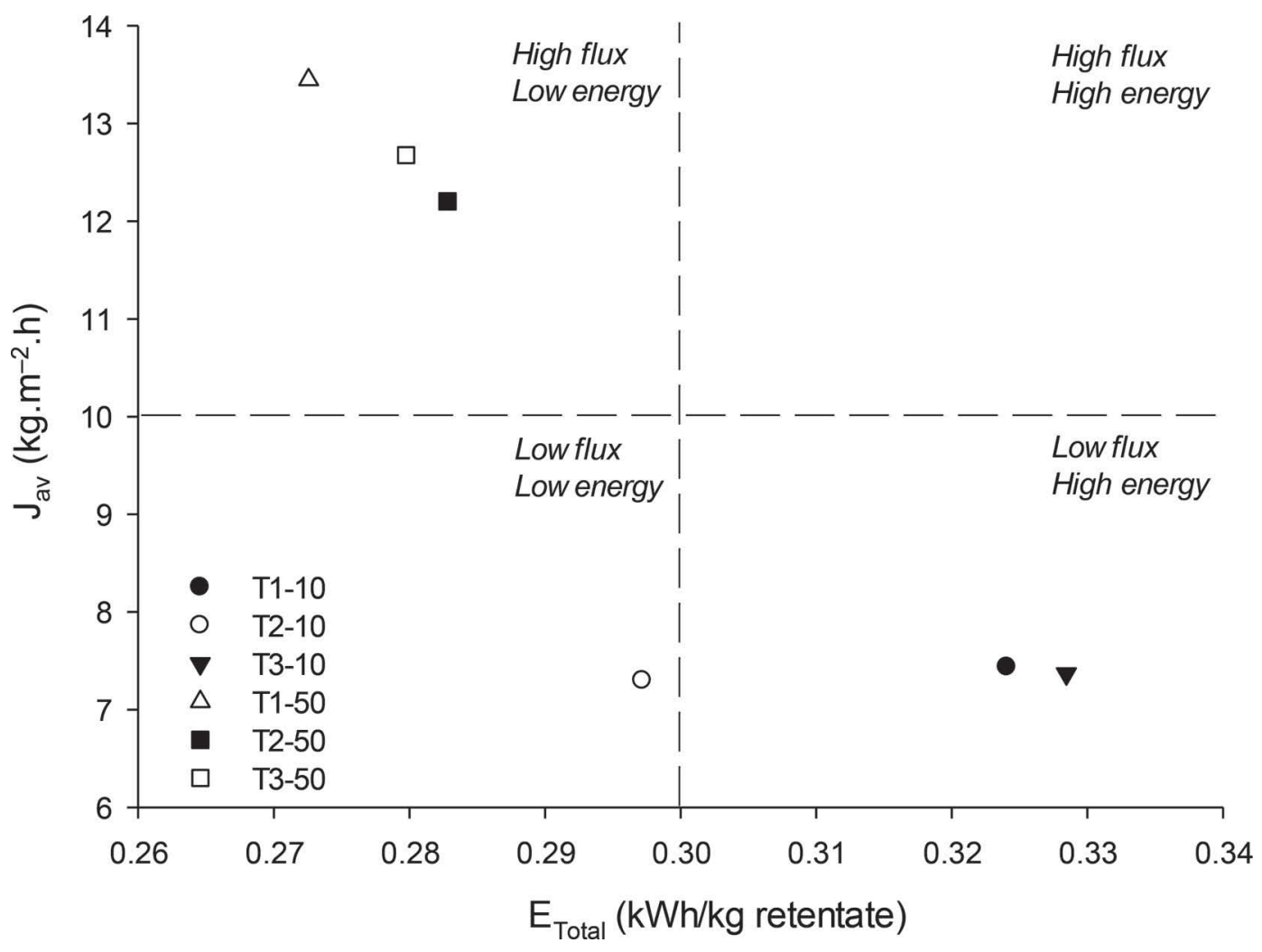

Figure 3. Efficiency ratio as illustrated by the relationship between mean permeation flux $\left(\mathrm{J}_{\mathrm{av}} ; \mathrm{kg} / \mathrm{m}^{2} \cdot \mathrm{h}\right)$ at volume concentration ratio of $3.6 \times$ and total energy consumption $\left(\mathrm{E}_{\mathrm{Total}}, \mathrm{kWh} / \mathrm{kg}\right.$ of retentate) for dynamic and constant transmembrane pressure $(\mathrm{T} 1=672 \mathrm{kPa} ; \mathrm{T} 2=465$ $\mathrm{kPa}$; $\mathrm{T} 3=$ dynamic flux) at $10^{\circ} \mathrm{C}$ and $50^{\circ} \mathrm{C}$.

\section{ACKNOWLEDGMENTS}

The authors acknowledge the financial support by Natural Sciences and Engineering Research Council of Canada (NSERC), Novalait Inc. (Quebec, QC, Canada), Fonds de Recherche Nature et Technologies du Québec (FRQNT, Quebec, QC, Canada), and the Canadian Dairy Commission (CDC, Ottawa, ON, Canada).

\section{REFERENCES}

AOAC International. 2000. Official Methods of Analysis. X17th ed. AOAC International, Gaithersburg, MD.

Bazinet, L., D. Ippersiel, C. Gendron, J. Beaudry, B. Mahdavi, J. Amiot, and F. Lamarche. 2000. Cationic balance in skim milk during bipolar membrane electroacidification. J. Membr. Sci. 173:201-209

Brule, G., J. L. Maubois, and J. Fauquant. 1974. Etude de la teneur en éléments minéraux des produits obtenus lors de l'ultrafiltration du lait sur membrane. Lait 54:600-615.

Carić, M. D., S. D. Milanović, D. M. Krstić, and M. N. Tekić. 2000. Fouling of inorganic membranes by adsorption of whey proteins. J. Membr. Sci. 165:83-88.

Cheryan, M. 1998. Ultrafiltration and Microfiltration Handbook. Technomic Publishing Company Inc., Lancaster, PA.

Cheryan, M., and K. P. Kuo. 1984. Hollow fibers and spiral wound modules for ultrafiltration of whey: Energy consumption and performance. J. Dairy Sci. 67:1406-1413.
Gésan, G., G. Daufin, and U. Merin. 1994. Whey crossflow microfiltration using an M14 Carbosep membrane: Influence of initial hydraulic resistance. Lait 74:267-279.

Grandison, A. S., W. Youravong, and M. J. Lewis. 2000. Hydrodynamic factors affecting flux and fouling during ultrafiltration of skimmed milk. Lait 80:165-174.

Guinee, T. P., B. T. O'Kennedy, and P. M. Kelly. 2006. Effect of milk protein standardization using different methods on the composition and yields of Cheddar cheese. J. Dairy Sci. 89:468-482.

Horne, D. S. 2006. Casein micelle structure: Models and muddles. Curr. Opin. Colloid Interface Sci. 11:148-153.

Huang, J., L. Liu, G. Zeng, X. Li, L. Peng, F. Li, Y. Jiang, Y. Zhao, and X. Huang. 2014. Influence of feed concentration and transmembrane pressure on membrane fouling and effect of hydraulic flushing on the performance of ultrafiltration. Desalination 335:18.

ISO-IDF. 2001a. Milk-Determination of nitrogen content-Part 1: Kjeldahl method. Standard ISO 8968-1-IDF 20-1. International Dairy Federation, Brussels, Belgium; International Organization for Standardization (ISO), Geneva, Switzerland.

ISO-IDF. 2001b. Milk-Determination of nitrogen content-Part 4: Determination of non-protein-nitrogen content. Standard ISO 89684-IDF 20-4. International Dairy Federation, Brussels, Belgium; International Organization for Standardization (ISO), Geneva, Switzerland.

Kapsimalis, D. J., and R. R. Zall. 1981. Ultrafiltration of skim milk at refrigerated temperatures. J. Dairy Sci. 64:1945-1950.

Kelly, P. 2011. Milk protein products. Pages 879-886 in Encyclopedia of Dairy Sciences. 2nd ed. J. W. Fuquay, P. F. Fox, and P. L. H. McSweeney, ed. Academic Press, London, UK.

Liu, D. Z., M. G. Weeks, D. E. Dunstan, and G. J. O. Martin. 2014. Alterations to the composition of casein micelles and retentate se- 
rum during ultrafiltration of skim milk at 10 and $40^{\circ} \mathrm{C}$. Int. Dairy J. 35:63-69.

Luo, X., L. Ramchandran, and T. Vasiljevic. 2015. Lower ultrafiltration temperature improves membrane performance and emulsifying properties of milk protein concentrates. Dairy Sci. Technol. 95:15-31.

Macedo, A., E. Duarte, and R. Fragoso. 2015. Assessment of the performance of three ultrafiltration membranes for fractionation of ovine second cheese whey. Int. Dairy J. 48:31-37.

Miller, D. J., S. Kasemset, D. R. Paul, and B. D. Freeman. 2014. Comparison of membrane fouling at constant flux and constant transmembrane pressure conditions. J. Membr. Sci. 454:505-515.

Muthukumaran, S., S. E. Kentish, G. W. Stevens, M. Ashokkumar, and R. Mawson. 2007. The application of ultrasound to dairy ultrafiltration: The influence of operating conditions. J. Food Eng. $81: 364-373$.

Piry, A., A. Heino, W. Kühnl, T. Grein, S. Ripperger, and U. Kulozik. 2012. Effect of membrane length, membrane resistance, and filtration conditions on the fractionation of milk proteins by microfiltration. J. Dairy Sci. 95:1590-1602.

Pompei, C., P. Resmini, and C. Peri. 1973. Skim milk protein recovery and purification by ultrafiltration- Influence of temperature on permeation rate and retention. J. Food Sci. 38:867-870.

Purkait, M. K., S. DasGupta, and S. De. 2004. Resistance in series model for micellar enhanced ultrafiltration of eosin dye. J. Colloid Interface Sci. 270:496-506.
Razavi, M. A., A. Mortazavi, and M. Mousavi. 2003. Dynamic modelling of milk ultrafiltration by artificial neural network. J. Membr. Sci. 220:47-58.

Rehman, S., N. Y. Farkye, and B. Yim. 2003. Use of dry milk protein concentrate in pizza cheese manufactured by culture or direct acidification. J. Dairy Sci. 86:3841-3848.

Rinaldoni, A. N., C. C. Tarazaga, M. E. Campderrós, and A. P. Padilla. 2009. Assessing performance of skim milk ultrafiltration by using technical parameters. J. Food Eng. 92:226-232.

Samuelsson, G., P. Dejmek, G. Trägårdh, and M. Paulsson. 1997. Minimizing whey protein retention in cross-flow microfiltration of skim milk. Int. Dairy J. 7:237-242.

Sikand, V., P. S. Tong, S. Roy, L. E. Rodriguez-Saona, and B. A. Murray. 2011. Solubility of commercial milk protein concentrates and milk protein isolates. J. Dairy Sci. 94:6194-6202.

St-Gelais, D., S. Haché, and M. Gros-Louis. 1992. Combined effects of temperature, acidification, and diafiltration on composition of skim milk retentate and permeate. J. Dairy Sci. 75:1167-1172.

Stade, S., M. Kallioinen, T. Tuuva, and M. Mänttäri. 2015. Compaction and its effect on retention of ultrafiltration membranes at different temperatures. Separ. Purif. Tech. 151:211-217.

$\mathrm{Xu}, \mathrm{T}$., and J. Flapper. 2011. Reduce energy use and greenhouse gas emissions from global dairy processing facilities. Energy Policy $39: 234-247$. 